


\section{Food Economic Report 2017 of the Netherlands}

\section{Summary}

P. Berkhout

This project was financed by the Dutch Ministry of Agriculture, Nature and Food Quality (formerly known as the Ministry of Economic Affairs) from the public-private partnership 'Koepel Economische Informatievoorziening'.

Wageningen Economic Research

Wageningen, January 2018

BOOKLET

ISSN 0924-0764 
Berkhout, P., 2018. Food Economic Report 2017 of the Netherlands;

Summary. Wageningen, Wageningen Economic Research, Booklet.

16 pp.; 0 fig.; 5 tab.; 0 ref.

This booklet offers an English summary of the Voedsel-Economisch Bericht 2017 and Duurzaamheid en inkomens in de land- en tuinbouw

(www.agrofoodportal.com). It presents a survey of the economic state of Dutch agribusiness. Attention is paid to the development of the agricultural complex, the food industry, the retail chain and the consumption of food. The booklet then proceeds to describe the production structure in the primary agricultural sector, profitability and income formation as well as the environmental performance of the agricultural sector.

This publication can be downloaded at https://doi.org/10.18174/430432 or at www.wur.eu/economic-research (under Wageningen Economic Research publications).

(C) 2018 Wageningen Economic Research

P.O. Box 29703, 2502 LS The Hague, The Netherlands, $\mathrm{T}+31$ (0)70 33583 30, E communications.ssg@wur.nl, http://www.wur.eu/economic-research. Wageningen Economic Research is part of Wageningen University \& Research.

\section{(cc) BY-NC}

For its reports, Wageningen Economic Research utilises a Creative Commons Attributions 3.0 Netherlands license.

(C) Wageningen Economic Research, part of Stichting Wageningen Research, 2018

The user may reproduce, distribute and share this work and make derivative works from it. Material by third parties which is used in the work and which are subject to intellectual property rights may not be used without prior permission from the relevant third party. The user must attribute the work by stating the name indicated by the author or licensor but may not do this in such a way as to create the impression that the author/licensor endorses the use of the work or the work of the user. The user may not use the work for commercial purposes.

Wageningen Economic Research accepts no liability for any damage resulting from the use of the results of this study or the application of the advice contained in it.

Wageningen Economic Research is ISO 9001:2008 certified.

Wageningen Economic Research Booklet | Project code 2282300169

Cover photo: Shutterstock 


\section{Contents}

$\begin{array}{ll}\text { Preface } & 4\end{array}$

1 The Dutch agricultural sector 5

1.1 The agricultural complex 5

$\begin{array}{lll}1.2 & \text { Food and beverages industry } & 7\end{array}$

1.3 Retail chain and food consumption 7

1.4 Trade in agricultural products 11

2 The agricultural and horticultural sector 12

2.1 Number of holdings 12

2.2 Labour, land, and capital 13

2.3 The sector's income 14

$\begin{array}{ll}2.4 & \text { Environmental performance }\end{array}$ 


\section{Preface}

This booklet provides a summary of two publications, the Food Monitor 2017 (Voedsel-Economisch Bericht) and Sustainability and income development of the primary agricultural sector 2017 (Duurzaamheid en inkomens in de land-en tuinbouw). Both publications have been commissioned by the Dutch Ministry of Agriculture, Nature and Food Quality (formerly known as the Ministry of Economic Affairs).

The Food Monitor is the successor to the Annual Agricultural Report and offers a global survey of the Dutch food economy. Attention is paid to the development of the agricultural complex, the food industry, the retail chain and the consumption of food. Based on the Sustainability and income development of the primary agricultural sector report, this booklet then proceeds to describe the production structure in the primary agricultural sector, profitability and income formation as well as the environmental performance of the agricultural sector.

The full versions of both publications (in Dutch) are available online via www.agrofoodportal.com. Part of the information on this website is also available in English.

The Hague, January 2018

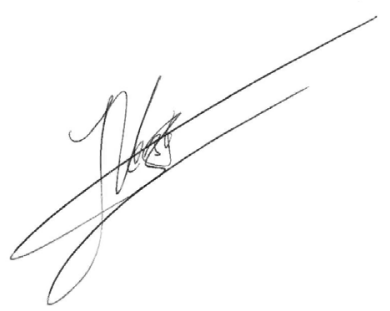

Prof.dr.ir. Jack (J.G.A.J.) van der Vorst

General Director Social Sciences Group

Wageningen University \& Research 


\section{The Dutch agricultural sector}

\subsection{The agricultural complex}

The agricultural sector - comprising agriculture, horticulture and fisheries is linked closely to other parts of the economy. For example, agricultural production is virtually impossible without provision of goods and services such as animal feed, fertiliser, energy, machinery, sheds, greenhouses, and veterinary and business services, whilst raw agricultural products require processing in the food industry, trade and distribution before they reach the consumer's table. One can view the entire set of direct and indirect activities surrounding the agricultural sector as one inter-related chain, which we often refer to as the agro (or agricultural) complex.

In this approach the primary sector and the processing industry for food and luxury items are the main focal point. The size of the agricultural complex is determined by what the Dutch primary sector and processing industry need from suppliers and logistics to produce the products. This approach has been developed over time, predominantly due to the wish to map a chain from farmer to consumer. For this reason the import and processing of products such as coffee, tea and cacao are included in the numbers, but the export of suppliers to foreign primary producers and processors is not.

The agro complex produces $8 \%$ of the national gross value added (GVA) The GVA from the entire Dutch agro complex was worth a good 48 million euro in 2015 (Table 1 ), which represented nearly $8 \%$ of the national gross value added. The share in the national total increased slightly between 2010 and 2013, because the agricultural complex suffered relatively less compared to the other economic sectors as a result of the financial-economic crisis that began in 2008. In 2014 and 2015 the national economy showed stronger growth than the agricultural sector, which led to a slight drop in the proportion of the agricultural complex. 
The agricultural complex provides a good $8 \%$ of national employment Employment in the entire agricultural complex has grown during recent years, reaching about 603,000 employment years in 2015 (Table 1), which represents $8.6 \%$ of the national total. This growth in the agricultural complex is entirely attributable to domestic raw materials as employment has increased in all supply chain links, with the exception of the distribution link.

Table 1 Gross value added and employment in the Dutch agricultural complex, 2010 and 2015

\begin{tabular}{|c|c|c|c|c|}
\hline & $\begin{array}{l}\text { Added } \\
\text { value } \\
\text { ( } x \text { billion } \\
\text { euros) } \\
\end{array}$ & $\begin{array}{l}\text { Added } \\
\text { value } \\
\text { ( } x \text { billion } \\
\text { euros) } \\
\end{array}$ & $\begin{array}{l}\text { x } 1,000 \\
\text { annual } \\
\text { labour } \\
\text { units }\end{array}$ & $\begin{array}{l}\text { x } 1,000 \\
\text { annual } \\
\text { labour } \\
\text { units } \\
\end{array}$ \\
\hline & 2010 & 2015 & 2010 & 2016 \\
\hline $\begin{array}{l}\text { Total - domestic, and imported } \\
\text { agricultural raw materials complex }\end{array}$ & 43.2 & 48.1 & 575.6 & 603.0 \\
\hline Share $(\%)$ in national total & 7.6 & 7.9 & 8.2 & 8.6 \\
\hline $\begin{array}{l}\text { Totals - imported agricultural raw } \\
\text { materials complex }\end{array}$ & 15.1 & 17.9 & 174.1 & 188.0 \\
\hline Share (\%) in national total & 2.7 & 2.9 & 2.5 & 2.7 \\
\hline $\begin{array}{l}\text { Total - domestic agricultural raw } \\
\text { materials complex }\end{array}$ & 28.1 & 30.2 & 401.5 & 415.0 \\
\hline Share (\%) in national total & 4.9 & 5.0 & 5.7 & 5.9 \\
\hline Primary production & 9.1 & 9.4 & 164.7 & 161.6 \\
\hline Processing & 4.2 & 5.2 & 54.7 & 62.9 \\
\hline Supply & 11.8 & 12.4 & 144.9 & 156.9 \\
\hline Distribution & 3.0 & 3.2 & 37.2 & 33.5 \\
\hline
\end{tabular}

Source: CBS (Statistics Netherlands) - processed by Wageningen Economic Research.

Export provides a significant contribution to gross value added (GVA) and employment in the agricultural complex An important part of the activities of the agricultural complex is associated with exporting processed and raw agricultural materials. Export contributes about three quarters of GVA and employment in the sector of the agricultural complex based on domestic raw materials. The dependence on exports over the entire agricultural complex is slightly 
lower, but still over 70\%. Dependence on exports varies slightly for different parts of the agricultural complex, ranging from $66 \%$ for the arable farming sector to $80 \%$ in the greenhouse horticulture complex.

\subsection{Food and beverages industry}

Measured by sales and employment, the food industry is the largest branch of industry. In 2016 the amount of companies active in the food industry grew from 5,210 to 5,275. The employment in 2015 increased by $2 \%$ to almost 156,000 people. Several industrial sectors are included in these figures, from fruit and vegetable processing to abattoirs, meat products industry, bakeries and baked goods. The alcohol and tobacco industries are not included.

Almost one in six industrial employees works in the food industry. Although the amount of jobs in the food industry increased in 2015, their share of jobs in the total number of jobs in industry stayed roughly the same. The net revenue increased by over 3 billion to 65.2 billion euros. With a share of almost $20 \%$ in the revenue of the Dutch industry, the food industry represents an important and growing segment.

The GVA of the food industry is 11.6 billion euros, which is a share of around 15\% until 2013 and around 16\% since 2014 in the GVA of total industry. The GVA of the entire industry represents less than $12 \%$ of the total GVA of the Netherlands. This is because of the size of the commercial services sector, which represents almost $54 \%$ of the total GVA of the Netherlands.

\subsection{Retail chain and food consumption}

In 2015, the total foodstuff turnover through all sales channels in the Netherlands reached a good fifty seven billion euros (Table 2). That sum involves retail sales (supermarkets and other retail outlets, e.g. markets and specialised businesses), and the food service sector (hotels and restaurants, catering, leisure and sales points 'on the move'). The revenue from food and drinks in retail in 2016 represents around 37 billion euros. 
Roughly half of all food revenues, 29 billion euros in 2016, are generated by supermarkets which makes them the most important sales channel of food and drinks. The revenues of supermarkets have increased by approximately 1 billion euros compared to 2015. The food service sector accounts for almost a third of all revenues. Together cafés, hotels and restaurants; the recreational sector; catering; and roadside sales points saw 18 billion euros in sales, an increase of 0.6 billion euros compared to 2015 .

Table 2 Food and drink turnover in the Netherlands, 2015 and 16, in billions of euros a)

\begin{tabular}{llrr}
\multirow{2}{*}{$\boldsymbol{R e t a i l}$} & & 2015 & $\mathbf{2 0 1 6}$ \\
\hline & & $\mathbf{3 6 . 3}$ & $\mathbf{3 7 . 3}$ \\
\hline \multirow{2}{*}{ Foodservice } & Supermarkets & 28.0 & 29.0 \\
\hline & & 8.3 & 8.3 \\
\hline & Hotels/restaurants/catering & $\mathbf{1 7 . 7}$ & $\mathbf{1 8 . 3}$ \\
\hline & Leisure b) & 10.9 & 11.3 \\
\hline & Catering & 1.2 & 1.3 \\
\hline Food total & On the move & 3.2 & 3.2 \\
\hline
\end{tabular}

a) Due to changes in the data sources, the calculation of the turnover for 2015 is different from previous editions of the Food Economic Report; b) Expenditure in recreation and amusement parks, etc.

Source: Foodstep (a Dutch food market advisory service), CBS and our own data.

The large supermarket chains such as Ahold (Albert Heijn), Jumbo, Lidl, and Aldi buy independently, while the smaller chains are members of the wholesale purchasing cooperative Superunie. Ahold tops the league for turnover and market share in the Netherlands. In 2016, Ahold realised almost 13 billion euros of turnover, which represents a good $35 \%$ market share. Jumbo comes in a safe second, with a good $18 \%$ market share and turnover of nearly seven billion euros in 2016. Lidl and Aldi are in third and fourth position.

\section{Increased household expenditure on food}

In 2016, Dutch households spent around 300 billion euros on food, semiluxury foods and beverages, tobacco, consumer durables, energy, water, fuel, and services, including hotels, restaurants, and catering. Almost 
45 billion euros was spent on food and semi-luxury foods (Table 3 ). From that sum, nearly 29 billion euros of the expenditure was on foodstuffs, e.g. dairy products, meat, and fish, potatoes, vegetables and fruit, and bread. The remaining expenditure was on semi-luxury items such as ice creams, candies, beverages and tobacco. Expenditure on food, semiluxury foods, beverages and tobacco amounted to $14.8 \%$ of total consumer spending on goods and services in 2016. This proportion has remained quite stable for a few years (Table 3). Expenditure on hotels, restaurants and cafés and recreation are included in the calculations for expenditure on services and are not addressed in this section.

Table 3 Household consumer expenditure (billions of euros) a) 2012-2015

\begin{tabular}{|c|c|c|c|c|}
\hline & 2013 & 2014 & 2015 & 2016 \\
\hline Foodstuffs & 26.8 & 27.0 & 27.8 & 28.5 \\
\hline $\begin{array}{l}\text { Semi-luxury foods, beverages and } \\
\text { tobacco }\end{array}$ & 15.5 & 15.7 & 15.9 & 16.1 \\
\hline Total on food and semi-luxury items b) & 42.2 & 42.7 & 43.7 & 44.6 \\
\hline $\begin{array}{l}\text { Total consumer expenditure on goods } \\
\text { and services }\end{array}$ & 284.4 & 287.5 & 294.1 & 300.3 \\
\hline $\begin{array}{l}\text { Share (\%) foodstuffs and semi-luxury } \\
\text { foods, drinks, and tobacco }\end{array}$ & 14.9 & 14.9 & 14.8 & 14.8 \\
\hline
\end{tabular}

a) At current prices.

b) Relates to consumer spending through trade or directly. Expenditure on the catering industry is not included.

Source: CBS - processed by Wageningen Economic Research.

Online sales is a growing market

The online delivery and collection services for food in the Netherlands have generated a total of approximately 2 billion euros in revenue during 2016 according to estimates. That includes the revenues generated by online services of existing supermarkets, estimated at 0.6 billion euros. Ten years earlier food was barely sold online.

The traditional supermarkets are increasingly expanding their online activities. Almost all service supermarkets have an option to order online. The ordered groceries can be collected or delivered at home. Albert Heijn and Jumbo are the market leaders in online food retail, together 
representing an estimated $80 \%$. Their size of scale and loyal-to-formula customers have made it possible to quickly make the jump to online sales. Since 2015 there is a new player that focuses exclusively on online activities: Picnic. Picnic positions itself as an entirely online supermarket with delivery service and has no physical shops. In 2017 Picnic operates exclusively in regions where there are enough customers, yet they have plans for further expansion. The traditional supermarkets' online services already have a large country-wide coverage. In 2016 Picnic made 30 million euros in revenue and the supermarket now has the ambition to grow to 100 million euros in 2017. Other parties such as Shobr are trying to gain a foothold in the online groceries market.

The expectation is that the online market in food will continue to grow during the next decade, though the physical sales channels will remain popular.

Physical supermarkets will focus more on the 'fresh' experience and service, while their warehouse function will be moved towards online distribution. Furthermore, the consumer will increasingly choose for more convenience and eating on the go; Ahold has catered to this trend through the rise of $\mathrm{AH}$ to go shops with a smaller convenience store variety in busy city centres, at train stations and in business parks. Hotels, restaurants and cafés and retail will become increasingly interwoven, further blurring the line between the different types of sales channels. Internet and social media offer retailers and processors a new way to clarify to the consumer who supplies their food and where the products come from. In addition, they offer a chance to primary producers to directly engage with their customers and therefore to shorten the chain by distributing their own products themselves.

Consumption of foodstuffs from sustainable and organic production keeps growing

Between 2015 and 2016 the revenues of organic products increased by $8 \%$. The market share of organic products therefore also increased, but remains relatively limited at $3 \%$.

Most expenditures on organic food occur in supermarkets, representing 648 million euros. The speciality shops for sustainable, predominantly organic, food are another important channel for organic food sales, 
representing 336 million euros of revenue. The non-domestic market (hotels, restaurants and cafés, catering, etc.) represent revenues of 187 million euros. It is estimated that consumers spent more than 1.4 billion euros in total on organic food products in 2016 .

\section{$1.4 \quad$ Trade in agricultural products}

Slight increase in exports

In 2016, Dutch agricultural exports exceeded 84 billion euros (Comtrade, 2016), an increase of $3 \%$ compared to 2015 . After the United States, the Netherlands is the second biggest agricultural exporter in the world. The exports include a wide range of products, which go primarily to immediate neighbours. In 2016, 78\% of Dutch agricultural exports went to EU countries. This percentage has stayed relatively consistent for the past few years. Germany, Belgium, the United Kingdom and France accounted for $55 \%$ of the exports. The most important export products are vegetables and fruit, live animals and meat, and flowers and plants.

Import value of agricultural products into the Netherlands increases again

In 2016, the value of imported agricultural products was 57 billion euros, an increase of $1.5 \%$ compared to 2015 . Imports from EU countries have remained fairly stable at around $60 \%$. The most important source countries for imports from within the EU are Germany, Belgium, France, and the United Kingdom, with a combined share of $43 \%$ of the total import value. The share is stable to slightly decreasing. The important import source countries outside the EU are Brazil, the United States (soy), and Ivory Coast (cocoa). The share of imports coming from those countries is still limited to about $11 \%$. Just like exports, imports are multidimensional. Important examples of imported products include vegetables and fruit, meat, live animals, and cacao.

More than half of Dutch agricultural exports are foodstuffs Agricultural trade figures are the sum total of data gathered on more than 2,300 commercial codes, which cover different products, ranging from seeds to processed meat. More or less directly consumable food or beverages represented about 59\% of Dutch agricultural exports in 2016, and amounted to 50 billion euros. 


\section{The agricultural and horticultural sector}

\section{$2.1 \quad$ Number of holdings}

In 2016, the number of agricultural and horticultural businesses fell by 8,200 to 55,681 , a decrease of $12.9 \%$ (Table 4 ). This is an exceptionally large reduction caused by changes in the registration of agricultural and horticultural holdings. The main change is that holdings not registered with an agricultural activity in the Chamber of Commerce Trade Register are no longer included in the agricultural census. According to the preliminary figures for 2017, the total number of agricultural and horticultural holdings dropped on balance by around 900 down to 54,800 . This is equivalent to a reduction of $1.6 \%$, which is below the long-term average of $2 \%$ to $3 \%$ per year.

The change in registration also led to a one-time substantial decrease in 2016 in the area of cultivated land in use by the registered agricultural and horticultural holdings.

Table 4 Developments in the numbers of holdings and employees, and total area of farmland from 2000 onwards

\begin{tabular}{lrrrr} 
& 2000 & 2005 & 2010 & 2016 \\
$\begin{array}{l}\text { Number of agricultural and horticultural } \\
\text { farms (x 1,000) }\end{array}$ & 97,389 & 81,750 & 72,324 & 55,681 \\
\hline Number of workers (x 1,000) & 280.9 & 235.7 & 212.0 & 173.0 \\
\hline Area of farmland (x 1,000 ha) & $1,975.5$ & $1,937.7$ & $1,872.3$ & $1,796.3$ \\
\hline
\end{tabular}

Source: CBS (Statistics Netherlands) agricultural census, processed by Wageningen Economic Research. 


\subsection{Labour, land, and capital}

The total number of persons who are regularly at work in the primary agricultural and horticultural sector fell by 13,000 to just under 173,000 in 2016. This significant reduction of $7 \%$ is also due to the changes in registration of agricultural and horticultural holdings in 2016. The majority of the holdings no longer included in the registration are very small farms without employees. The decrease in the number of people working in the sector is almost entirely accounted for by members of the agricultural families.

These figures exclude flexible labour (temporary workers from agencies and personnel with short-term contracts). The regular employees usually have full-time jobs all year round, while flexible employees, particularly in the open ground horticulture sector, only come in for peak periods. The total size of the flexible workforce is therefore difficult to determine.

Share of grassland still increasing

Relative to 2015 the acreage decreased by approximately 50,000 hectares to 1.79 million hectares, as seen in Table 4, representing a reduction of $2.7 \%$. The reduction of the acreage in 2017 by 6,000 hectares, a decrease of $0.3 \%$, based on provisional figures, is close to the long-term average.

Of the total area of cultivated land, $54 \%$ is now in use as grassland (permanent, temporary and natural), $12 \%$ for green fodder crops, $28 \%$ for other arable production, $5 \%$ for open-field horticulture and $0.5 \%$ for greenhouse horticulture.

Most businesses largely financed by private equity

There has been a further increase in capital intensity in agriculture and horticulture. The average balance sheet value of Dutch agricultural and horticultural holdings rose to 2.9 million euros in 2016; an increase of 100,000 euros compared to the previous year. This increase is primarily due to an increase in the average size of holdings and the increases in the price of farmland. More than two thirds of the balance sheet total is financed with equity capital. 
Up until 2007, the long-term liabilities of the agricultural and horticultural holdings rose faster than the total balance sheet value, leading to a decrease in solvency during that period. After 2007, average solvency remained reasonably stable, at around $67 \%$ to $68 \%$. In 2016 , solvency rose to $69 \%$, but the ratio varies greatly between holdings. The value of the solvency ratio indicates that most businesses are largely financed with equity capital. The annual formation of equity capital of agricultural and horticultural holdings takes place on the basis of the revaluation of the holding's assets and other movements of liquid assets resulting from savings, legacies received and other movements in assets.

It is important, from a risk management perspective, for holdings to possess an adequate financial buffer to absorb fluctuations in income. Holdings with a low solvency are very susceptible to fluctuations of this nature. On $10 \%$ of the holdings, the solvency ratio is lower than $35 \%$. Generally speaking, these are holdings with relatively high payment obligations relating to interest payments and loan repayments. In just under $20 \%$ of the holdings, borrowed capital exceeds equity capital.

\subsection{The sector's income}

The average farm income for agricultural and horticultural businesses in 2017 is estimated at around 70,000 euros per unpaid annual labour unit. This is an increase of 20,000 euros compared with 2016 and a very high figure from an historical perspective. Each year the agriculture and horticulture sector sees significant differences in income, both within a given sector and among the various sectors. In 2017, dairy farmers experienced the sharpest rise in income thanks to a good price for milk. There was also a strong increase in income for pot plant and bedding plant businesses and for sow farms. Arable farmers were faced with lower prices for ware potatoes and onions, which resulted in reduced incomes. Extreme differences in income were experienced by the laying hen farming sector as a consequence of the Fipronil scandal. Businesses affected by the crisis suffered great economic losses. On the other hand, in the second half of the year, businesses which were not affected by the crisis and which also produce eggs for the free market benefited from the sharp increase in the price of eggs resulting from interruptions to production at the businesses affected by the Fipronil scandal. 


\subsection{Environmental performance}

The environmental impact of the primary agriculture and horticulture sector is visible and measurable through different environmental indicators. There is wide ranging variation between developments connected with each environmental issue.

The agricultural sector is the main source of ammonia emissions. Since 2010, ammonia emissions have remained stable at around 110-115 million $\mathrm{kg}$ and the objective for 2020 agreed upon at European level (maximum of 128 million $\mathrm{kg}$, including emissions from sources other than agriculture) appears to be achievable. However, the level of nitrogen deposition in the Netherlands is too high for the country to achieve its biodiversity objectives. Even though the Dutch agricultural sector has reduced its emissions by more than half since 1990, ammonia emissions still amount to $60 \mathrm{~kg}$ of ammonia per hectare of agricultural land, making it the highest level in the EU.

There has not been any real decline in the use of crop protection agents in recent years, with the amount of active ingredient fluctuating around the 9 million $\mathrm{kg}$ mark. Around $40 \%$ of the products used are fungicides. Fluctuations in usage are closely related to the weather. In years with damp summers, for example, fungal outbreaks are more severe than in dry years. A cold and, consequently, slow start to the cultivation season also affects the use of crop protection agents, as this retards the development of diseases and infestations.

Alongside the use expressed in $\mathrm{kg}$ of active ingredient, the environmental impact per $\mathrm{kg}$ of active ingredient is also of importance: the environmental impact per $\mathrm{kg}$ of active ingredient has declined for many years due to the continual elimination of ingredients with a relatively high impact.

The emission of greenhouse gases has decreased significantly since 1990. The Paris climate agreement stipulates an $85 \%$ to $95 \%$ reduction of greenhouse gases in the Netherlands by 2050 compared to 1990 which necessitates more stringent measures. 
There has been a strong reduction in surpluses of nitrogen and phosphate per hectare as a consequence of the export of manure, a reduction in the use of artificial fertiliser and lower phosphate levels in feed and thus in manure. The policy objective of a maximum of 50 milligrams of nitrate per litre of groundwater has been achieved nearly everywhere; it is only in the southern sandy regions that the average nitrate concentration in the upper groundwater still exceeds the policy objective. The nitrogen and phosphate norms are still exceeded considerably in the surface water.

The total production of phosphate and nitrogen is subject to a fixed ceiling; the excretion of nutrients must not exceed 173 million $\mathrm{kg}$ of phosphate and 504 million $\mathrm{kg}$ of nitrogen (including gaseous losses) in any one year. Although both objectives were achieved in 2014, the limit for phosphate was exceeded in both 2015 and 2016.

Based on current agricultural practices, it will not be possible to achieve the nutrient objectives of the Water Framework Directive (WFD) in large parts of the Netherlands.

Table 5 Development of the environmental impact of agriculture and horticulture, 2000-2016

\begin{tabular}{lrrrrrr} 
& 2000 & 2005 & 2010 & 2015 & 2016 \\
$\begin{array}{l}\text { Use of crop protection agents (in million } \\
\text { kg of active substance) }\end{array}$ & 9.644 & 9.309 & 9.288 & 8.698 & N/A \\
\hline $\begin{array}{l}\text { Greenhouse gas emissions (in billion } \\
\begin{array}{l}\mathrm{CO}_{2} \text { equivalents, IPPC2013) } \\
\text { Surplus of nitrogen (N, kg per hectare) }\end{array}\end{array}$ & 28.8 & 26.4 & 29.1 & 27.4 & 27.2 \\
\hline $\begin{array}{l}\text { Surplus of phosphates ( } \mathrm{P}_{2} \mathrm{O}_{5}, \mathrm{~kg} \text { per } \\
\text { hectare) }\end{array}$ & 23 & 183 & 11 & 3 & N/A \\
\hline Ammonia emissions (in million $\mathrm{kg})$ & 161 & 136 & 118 & 111 & 111 \\
\hline
\end{tabular}

N/A: not available.

Sources: Nefyto - RIVM (Dutch National Institute for Public Health and the Environment)/CBS, Milieucompendium (Environment Compendium), various years. 

The mission of Wageningen University and Research is "To explore the potential of nature to improve the quality of life". Under the banner Wageningen University \& Research, Wageningen University and the specialised research institutes of the Wageningen Research Foundation have joined forces in contributing to finding solutions to important questions in the domain of healthy food and living environment. With its roughly 30 branches, 5,000 employees and 10,000 students, Wageningen University \& Research is one of the leading organisations in its domain. The unique Wageningen approach lies in its integrated approach to issues and the collaboration between different disciplines.

Wageningen Economic Research

P.O. Box 29703

2502 LS Den Haag

The Netherlands

E communications.ssg@wur.nl

www.wur.eu/economic-research

\section{BOOKLET}

ISSN 0924-0764 